\title{
Eksistensi Prinsip-prinsip Keadilan dalam Sistem Hukum Perdagangan Internasional
}

\author{
Emmy Latifah*
}

\begin{abstract}
Abstrak
Ide mengenai keadilan telah berkembang seiring perkembangan kehidupan manusia, paradigma, dan nilai-nilai yang dianutnya. Dengan demikian, keadilan dapat diartikan berbeda-beda tergantung pada siapa, kapan, dimana, dan dalam konteks apa keadilan dimaknai. Demikian pula halnya yang terjadi pada sistem hukum perdagangan internasional, prinsip keadilan pada sistem perdagangan internasional yang dilakukan di bawah aturan dan prosedur WTO telah memainkan peran yang penting, terutama dalam kaitannya dengan pendistribusian hak dan kewajiban yang bersifat fundamental dan cara menentukan pembagian keuntungan dari kerja sama sosial yang ada didalamnya. Dalam hal ini prinsip keadilan diperlukan dalam rangka menanyakan apakah keputusan sosial yang dihasilkan oleh WTO benar dan konsisten dengan nilai-nilai yang ada di dalamnya. Hasil penelitian menunjukkan bahwa prinsip keadilan yang terdapat dalam aturan WTO mengandung dua makna yaitu 'the equality of opportunity' dan 'keadilan distributif'. Equality of opportunity dapat diwujudkan apabila prinsip reciprocity (timbal balik) ditegakkan baik dalam hal pengurangan hambatan perdagangan, akses pasar, maupun penyelesaian sengketa. Keadilan distributif berarti bahwa perdagangan internasional merupakan sarana untuk mewujudkan hubungan dagang yang saling menguntungkan diantara negara anggota.
\end{abstract}

Kata kunci: keadilan distributif, prinsip reciprocity, sistem hukum perdagangan internasional, the equality of opportunity, WTO.

\section{The Existence of Principles of Justice in International Trade Law System}

\begin{abstract}
The notion of justice has evolved along with the development of human being, paradigms, and their values. Therefore, justice can be interpreted differently, depends on who, when, where, and in what context people define it. It is also the case for the international trade law system. The principle of justice in the international trading system, conducted under the rules and procedures of the WTO, has played an important role, especially in relation to the distribution of obligations and fundamental rights, and the distribution of benefit from social cooperation within. In this case, the principle of justice is needed in order to inquire whether WTO's social decisions are proper and consistent with the values that exist within The results show that the principle of justice in the WTO rules contains two meanings: 'the equality of opportunity' and 'the distributive of justice'. The Equality of opportunity can be realized if the
\end{abstract}

PADJADJARAN Jurnal IImu Hukum Volume 2 Nomor 1 Tahun 2015 [ISSN 2460-1543] [e-ISSN 2442-9325]

* Dosen Hukum Internasional, Fakultas Hukum Universitas Sebelas Maret, Jl. Ir. Sutami 36A Surakarta 57126, emmy.latifah@yahoo.com, S.H. (Universitas Sebelas Maret), M.H (Universitas Padjadjaran), Dr. (Universitas Padjadjaran). 
reciprocity principle in the context of the reduction of trade barriers, market access, and dispute settlement are enforced. Distributive justice means that international trade is a tool to achieve a mutually beneficial trade among members.

Keywords: distributive justice, reciprocity principle, international trade law system, the equality of opportunity, WTO.

\section{A. Pendahuluan}

Keadilan mengandung nilai moral universal yang merupakan hak dan kebutuhan dasar manusia di seluruh dunia. ${ }^{1}$ Nilai moral keadilan tersebut menjadi cita-cita setiap bangsa yang didalamnya terdapat kepentingan berbagai golongan. ${ }^{2}$ Dalam hal ini, keadilan menjadi kesepakatan diantara berbagai unsur masyarakat yang menginginkan kehidupan bernegara yang adil dan makmur. Demikian pula dalam sistem hukum perdagangan internasional yang merupakan salah satu sistem sosial. Sistem sosial sebagaimana Rawls menyebutnya sebagai 'basic structure', terdiri dari lembaga utama, termasuk didalamnya terdapat perjanjian ekonomi dan perdagangan, maka ia berfungsi untuk mendistribusikan hak dan kewajiban fundamental dan menentukan pembagian keuntungan dari kerja sama sosial. Dalam kaitan dengan ruang lingkup World Trade Orgainization (WTO), hukum perdagangan internasional meliputi berbagai macam keputusan pengalokasian barang-barang sosial (social goods) seperti sumber daya, kesempatan ekonomi (economic opportunity), pengetahuan yang terkait dengan perdagangan (traderelated knowledge), preferensi, akses pasar, dan lain sebagainya. Prinsip keadilan berperan penting dalam rangka mempertanyakan apakah keputusan sosial yang dihasilkan oleh lembaga tersebut benar dan konsisten dengan nilai-nilai yang ada di dalam masyarakat tersebut.

WTO sebagai organisasi perdagangan dunia bertujuan mewujudkan liberalisasi perdagangan melalui berbagai macam cara termasuk penghapusan hambatan perdagangan, baik hambatan tarif maupun non tarif, serta mengurangi tindakan diskriminasi dalam hubungan dagang internasional. ${ }^{3}$ Namun di sisi lain, liberalisasi perdagangan menimbulkan ketidakadilan yang khususnya dirasakan oleh negaranegara berkembang, misalnya: negara-negara berkembang dipaksa untuk membuka akses pasarnya secara luas dan cepat sementara negara-negara maju

1 Kevin E. Hodges dan Daniel P. Sulmasy, "Moral Status, Justice, and the Common Morality: Challeges for the Principlist Account of Moral Change", Kennedy Institute of Ethics Journal, Vol. 23, Number 3, September 2013, hlm. 1.

2 Richard A. Posner, The Problematics of Moral and Legal Theory, Cambridge, Massachusetts, London, England: The Belknap Press of Harvard University Press, 1999, hlm. 19.

3 The Marrakesh Agreement Establishing the World Trade Organisation (WTO Agreement) of 15 April 1994, Paragraf 3. 
cenderung bermufakat untuk menjaga pasar mereka (menutup pasar) dari produkproduk yang berasal dari negara berkembang yang mampu bersaing dengan produk negara maju (produk pertanian, tekstil dan pakaian jadi), serta kurangnya kemampuan negara berkembang dalam memanfaatkan liberalisasi perdagangan akibat dari kurangnya sumber daya dan informasi. ${ }^{4}$ Tulisan ini bertujuan untuk mengkaji prinsip-prinsip keadilan yang terdapat dalam sistem hukum perdagangan internasional, dalam hal ini prinsip keadilan yang terkandung dalam aturan-aturan WTO.

\section{B. Pembahasan}

\section{Pengertian dan Perkembangan Konsep Keadilan}

Keadilan berasal dari kata 'adil' yang merupakan serapan dari Bahasa Arab 'al-'adl' yang sangat dekat maknanya dengan kata 'al-qisth' yang berarti lurus dalam jiwa, tidak dikalahkan oleh hawa nafsu, berhukum dengan kebenaran, tidak zalim, seimbang, setara, dan sebagainya. ${ }^{5}$ Dalam bahasa Indonesia, adil artinya sama berat, tidak berat sebelah, tidak memihak; sementara keadilan berarti sifat (perbuatan, kelakukan) yang adil, tidak berat sebelah, sepatutnya dan tidak sewenang-wenang. ${ }^{6}$ Dalam bahasa Inggris, istilah 'keadilan' disebut dengan beberapa terminologi yaitu justice, fairness, equity, dan impartiality. Istilah justice diartikan "the fair treatment of people, the quality of being fair or reasonable, the legal system used to punish people who have committed crimes". ${ }^{7}$ Fairness diartikan sebagai "the quality of treating people equally or in a way that is reasonable", equity diartikan sebagai "a situation in which everyone is treated equally" 9 dan impartially diartikan sebagai "treating all rivals or disputants equally; fair and just". ${ }^{10}$

Definisi dan konsep keadilan mengalami perkembangan seiring perkembangan kehidupan manusia. Perkembangan ini meliputi paradigma dan nilai-nilai yang dianutnya, sehingga keadilan dapat diartikan berbeda-beda tergantung pada siapa, kapan, dimana, dan dalam konteks apa keadilan dimaknai. ${ }^{11}$ Namun demikian, keragaman definisi dan konsep keadilan menunjukkan bahwa upaya untuk

4 Peter Van den Bossche, The Law and Policy of the World Trade Organization: Text, Cases and Materials, New York, Cambridge University Press, 2005, hlm. 15-16.

5 Ibn al-Arabiy, Lisan al-'Arab, Juz 11, Beirut, Daar Ehia al-Tourath, 1999, hlm. 430.

6 Kamus Besar Bahasa Indonesia, http://kbbi.web.id/adil, diakses 13 Maret 2010.

7 A.S. Hornby, Oxford Advanced Learner's Dictionary of Current English, Sixth Edition, Oxford, New York: Oxford University Press, 2000, hlm. 734.

8 Ibid., hlm. 474.

9 Ibid., hlm. 444.

10 Ibid., hlm. 678.

11 Teguh Prasetyo dan Abdul Halim Barkatullah, Ilmu Hukum dan Filsafat Hukum: Studi Pemikiran Ahli Hukum Sepanjang Zaman, Cetakan Kedua, Yogyakarta: Pustaka Pelajar, hlm. 58. 
mewujudkan suatu yang adil tidak mudah dilakukan. ${ }^{12}$

John Rawls dalam bukunya 'A Theory of Justice' menyebut konsep keadilan sebagai "justice as fairness". ${ }^{13}$ Keadilan menurut Rawls bertolak dari teori kontrak sosial yang dikemukakan oleh para pendahulunya J.J. Rousseau, Imanuel Kant, dan John Locke. Menurutnya, masyarakat adalah kumpulan orang-orang yang dalam hubungan di antara mereka berlaku aturan perilaku yang mengikat dan anggota masyarakat tersebut bertindak sesuai dengan aturan tersebut. ${ }^{14}$ Aturan ini kemudian menentukan pola kerja sama yang dibangun diantara mereka untuk meningkatkan kebaikan. ${ }^{15}$ Meskipun tujuan masyarakat adalah suatu kerja sama untuk mencapai keuntungan bersama, namun tetap saja timbul konflik yang disebabkan oleh kepentingan identitas. ${ }^{16}$

Konflik kepentingan identitas muncul karena adanya pola distribusi yang tidak tepat atas manfaat yang dihasilkan oleh anggota masyarakat. ${ }^{17}$ Masing-masing pihak dalam masyarakat menghendaki bagian yang lebih besar daripada yang lain. ${ }^{18}$ Oleh sebab itu, John Rawls mengidentifikasi masalah utama keadilan adalah merumuskan dan memberikan alasan pada sederet prinsip-prinsip yang harus dipenuhi oleh sebuah struktur dasar masyarakat yang adil, yaitu bagaimana prosedur pendistribusian pendapatan yang adil kepada masyarakat menuju masyarakat yang tertata dengan baik. ${ }^{19}$

Selanjutnya, masyarakat yang tertata dengan baik (well-order society) adalah masyarakat yang tidak hanya dirancang untuk meningkatkan kesejahteraan anggotanya, namun juga secara efektif diatur oleh konsepsi publik mengenai keadilan, yaitu: ${ }^{20}$

1. Dimana setiap orang menerima dan mengetahui bahwa orang lain menganut prinsip keadilan yang sama;

2. Institusi-institusi sosial dasar pada umumnya sejalan dengan prinsip-prinsip tersebut. Dalam hal ini lembaga dianggap adil ketika tidak ada pembedaan secara sewenang-wenang dalam memberikan hak dan kewajiban dan ketika aturan menentukan keseimbangan yang pas antara klaim-klaim yang saling berseberangan demi kemanfaatan kehidupan sosial;

3. Adanya prinsip keseimbangan dan kelayakan pada pembagian keuntungan dalam kehidupan sosial.

\footnotetext{
12 Nurhasan Ismail, Perkembangan Hukum Pertanahan Pendekatan Ekonomi-Politik (Perubahan Pilihan Kepentingan, Nilai Sosial dan Kelompok Diuntungkan), Yogyakarta: HuMa, 2007, hlm. 25.

13 John Rawls, A Theory of Justice (Revised Edition), Cambridge, MA: Harvard University Press, 1999, hlm. 4.

14 Ibid.

15 Ibid.

16 Ibid.

17 Ibid.

18 lbid.

19 Ibid.

20 Ibid.
} 
Sejalan dengan Rawls, Satjipto Rahardjo menyatakan bahwa pada hakikatnya keadilan berkaitan dengan pembagian sumber daya yang ada dalam masyarakat. ${ }^{21}$ Inti persoalan dalam keadilan dalam hal pembagian sumber daya adalah bagaimana anggota masyarakat itu memperoleh akses menuju sumber daya yang dibutuhkan. ${ }^{22}$ Terkait dengan keadaan ini, ada dua pola pembagian sumber daya menurut Satjipto Rahardjo, yaitu: pertama, berdasarkan kemampuan masingmasing orang; kedua, berdasarkan mekanisme pembagian yang diciptakan oleh masyarakat itu sendiri.

Terkait hal yang pertama, masalah akses atas sumber daya dipecahkan melalui kemampuan masing-masing individu secara alamiah. Dalam hal ini, berlaku rumus yang dikemukakan Thomas Hobbes yaitu homo homini lupus, seseorang adalah serigala bagi yang lain. Keadaan ini terjadi pada sistem masyarakat yang kacau balau, bukan pada masyarakat yang tertib. ${ }^{23}$ Sedangkan terkait hal yang kedua, masyarakat dengan sistem sosial tertentu akan memberikan pedoman kepada para anggotanya tentang bagaimana hendaknya hubungan-hubungan antarmereka itu dilaksanakan dalam mencapai sumber daya. ${ }^{24}$

Disinilah kemudian hukum memegang peranan penting dalam mengatur hubungan-hubungan yang ada dalam masyarakat untuk mencapai tujuan yang diinginkan. Hukum berfungsi untuk mengatur akses atas ke sumber daya yang akan diraih oleh masyarakat. Hukum melakukan pembagian sumber daya yang ada di dalam masyarakat.

Selanjutnya, beberapa hal yang dipersoalkan dalam pembagian sumber daya adalah: ${ }^{25}$

1. Kepada siapa sumber daya itu diberikan atau dibagikan?

2. Seberapa besar bagian yang diberikan kepada masing-masing penerima?

3. Apakah syarat yang harus dipenuhi untuk memperoleh bagian tersebut?

Menurut Garcia, salah satu cara untuk memahami ide keadilan adalah melalui 'right order'. ${ }^{26}$ Lembaga-lembaga sosial menghasilkan tatanan sosial melalui keputusan-keputusan mereka. Tugas 'keadilan' adalah untuk menanyakan apakah keputusan sosial dan hasil kelembagaan tersebut benar dan konsisten dengan nilainilai yang ada di dalam masyarakat tersebut. ${ }^{27}$ Salah satu cara untuk mengetahui apakah penyelidikan tentang keadilan relevan dengan situasi tertentu adalah dengan melihat apakah situasi tersebut melibatkan pengambilan keputusan publik

\footnotetext{
21 Satjipto Rahardjo, Ilmu Hukum, Cetakan Kelima, Bandung: Alumni, 2000, hlm. 160.

22 Ibid.

${ }^{23}$ Ibid., hlm. 161.

24 Ibid.

25 Ibid., hlm. 162.

${ }^{26}$ Frank J. Garcia, "Why Trade Law Needs a Theory of Justice", Proceedings of the Annual Meeting (American Society of International Law) Vol. 100, 2006, hlm. 376.

27 Ibid.
} 
tentang barang-barang sosial (social good). ${ }^{28}$ Ketika masyarakat menggunakan lembaga-lembaga sosial untuk membuat keputusan mengalokasikan barang sosial, hal ini termasuk domain keadilan. ${ }^{29}$ Keputusan-keputusan yang dibuat oleh institusi dan metode pengambilan keputusan akan dievaluasi berdasarkan prinsip-prinsip keadilan. ${ }^{30}$

\section{Konsep Keadilan Global dalam Tata Hukum Global}

Keadilan global (global justice) menjadi topik yang sering diperdebatkan sejak lima belas tahun terakhir ini. ${ }^{31}$ Hubungan antara hukum ekonomi internasional dan perdagangan internasional dengan keadilan global menjadi salah satu isu yang semakin diterima. ${ }^{32}$ Arti penting globalisasi terletak pada transformasi dan perluasan interaksi dan proses sosial yang lintas batas negara. ${ }^{33}$ Globalisasi menciptakan akibat sosial dan proses semacam itu menjadikan prinsip keadilan juga harus relevan di tingkat global. ${ }^{34}$

Ada tiga fungsi teori keadilan dalam hukum ekonomi internasional dan lembaga ekonomi internasional menurut Garcia. ${ }^{35}$ Pertama, teori keadilan dapat membantu menentukan tujuan yang tepat dari hukum dan kebijakan ekonomi internasional. ${ }^{36}$ Politik internasional dan nasional serta kepentingan nasional masing-masing negara yang terlibat memengaruhi tujuan dari perjanjian internasional dan organisasi ekonomi internasional. ${ }^{37}$ Kedua, teori keadilan dapat membantu mengevaluasi apakah hukum ekonomi internasional baik secara keseluruhan, maupun terbatas pada perjanjian-perjanjian tertentu itu adil atau tidak berdasarkan berbagai pemahaman tentang teori keadilan tersebut. ${ }^{38}$ Ketiga, teori keadilan dapat membantu mengevaluasi apakah hukum ekonomi internasional itu sah atau tidak (legitimate). ${ }^{39}$ Salah satu sebabnya adalah karena subjek-subjek hukum ekonomi internasional, khususnya lembaga internasional semakin lama semakin berkembang, dan mereka bersaing dengan lembaga nasional dalam hal legitimasi. ${ }^{40}$

\footnotetext{
28 Ibid.

29 Ibid.

30 Ibid., hlm. 377.

31 Joost Pauwelyn, “Just Trade”, Geo. Wash.Int'I L. Rev. Vol. 37, 2005, hlm. 559.

32 Joost Pauwelyn, "Just Trade Under Law: Do We Need A Theory of Justice for International Trade Relation?", Am. Soc'y Int'I L. Vol. 100, 2006, hlm. 375.

${ }^{33}$ Frank J. Gracia, "Globalization, Global Community and the Possibility of Global Justice", Boston College Law School, Paper 33, 2005, hlm. 2.

${ }^{34}$ Frank J. Garcia, "Three Takes on Global Justice", University of La Verne Law Review, Vol. 31 (2), 2010, hlm. 325.

${ }^{35}$ Frank J. Garcia, "Theories of Justice and International Economic Law", dalam John Linarelli (Ed.), Research Handbook on Global Justice and International Economic Law, Northhampton, Edward Elgar, 2013, hlm. 3-5.

${ }^{36} \mathrm{lbid}$.

37 Jeffrey L. Dunnoff, “Rethinking International Trade, PA. J. Int'I Econ. Law, Vol. 19, 1998, hlm. 347.

38 FrankJ. Garcia, Loc. cit.

39 Ibid.

40 Thomas Nagel, “The Problem of Global Justice”, Phil. \& Pub. Aff. Vol. 33, 2005, hlm. 146-147.
} 
Aaron James menguraikan bahwa konsep keadilan dalam konteks perdagangan internasional harus menjawab setidaknya tiga pertanyaan. Pertama, pada level dasar, apa yang harus dinilai sebagai 'adil' dan 'tidak adil' dalam konteks perdagangan? Kedua, isu keadilan seperti apa yang menjadi subjek penilaian? Ketiga, prinsip-prinsip moral apa yang harus dipenuhi agar perdagangan menjadi adil? ${ }^{41}$

Subjek keadilan dalam perdagangan internasional adalah praktek sosial internasional berkaitan dengan ketergantungan pasar (an international social practice of market reliance), dimana 'praktek negara-negara' saling bergantung pada pasar bersama (baik pasar barang, jasa, maupun modal) guna meningkatkan pendapatan nasional negara, sebagaimana Adam Smith menyebut sebagai 'The Wealth of Nations' ${ }^{42}$ Hal tersebut pada dasarnya dikarenakan setiap negara tidak bisa memenuhi kebutuhan hidupnya sendiri karena adanya perbedaan sumber daya. 'Praktik negara' yang dimaksud disini harus dibedakan antara transaksi pasar tertentu, aliran transaksi lintas negara maupun perdagangan tertentu atau kebijakan perdagangan yang mempengaruhi aliran transaksi (seperti kebijakan tentang tarif, kuota, safeguard, subsidi, dsb). Selain itu, 'praktek negara' di sini juga harus dibedakan dengan aturan internasional yang mengatur perdagangan dan kebijakan yang terkait dengan perdagangan, baik yang bersifat formal seperti aturan WTO maupun yang bersifat informal berupa understanding tentang bagaimana keseimbangan antara pasar dengan negara dapat dicapai. ${ }^{43}$

Praktik ketergantungan pasar dapat dilakukan dengan cara yang berbeda-beda, dengan berbagai konsekuensi bagi negara yang berbeda dan berdasarkan kelas masing-masing. ${ }^{44}$ Pilihan kolektif organisasi, baik melalui kesepakatan yang dinegosiasikan maupun melalui tindakan unilateral, tunduk pada batasan moral. ${ }^{45}$ Batasan moral yang paling utama adalah persyaratan kesetaraan struktural (structural equity) yang menyangkut bagaimana sistem perdagangan mendistribusikan manfaat dan beban yang ditimbulkan dari perdagangan kepada negara-negara yang berbeda dengan kelas yang berbeda pula. ${ }^{46}$

Selanjutnya, persyaratan mendasar dari kesetaraan struktural dalam sistem perdagangan internasional dapat dinyatakan melalui tiga prinsip. Prinsip pertama berkaitan dengan kerugian perdagangan (the harm of trade) seperti, pengangguran, penindasan pendapatan (wage suppression), serta ketidakstabilan pendapatan. ${ }^{47}$

\footnotetext{
41 Aaron James, "Theory of Fairness in Trade", Work in progress Faculty Profile System University of California Irvine, Nov. 2008, hlm. 1

42 Ibid.

43 Ibid.

${ }^{44}$ Ibid., hlm. 2.

45 lbid.

46 Ibid.

47 Ibid., hlm. 2-3.
} 
Berdasarkan the collective due care principle, perdagangan yang dilakukan oleh negara bertujuan untuk melindungi rakyat dari kerugian perdagangan (baik berupa hambatan perdagangan yang bersifat sementara seperti safeguard maupun bersifat permanen). ${ }^{48}$ Pada konteks ini, prinsip ini tidak menyediakan ruang untuk membandingkan tingkat manfaat bagi dua individu di dua negara yang berbeda. Artinya, prinsip ini tidak mempertimbangkan kerugian perdagangan bagi individu, apakah ia hidup di dalam sistem perdagangan atau tidak. ${ }^{49}$

Prinsip kedua dan ketiga berkaitan dengan manfaat perdagangan (gains of trade) berdasarkan teori perdagangan klasik. Kedua prinsip berikut ini terkait dengan pendapatan nasional yang berasal dari efisiensi alokasi dalam pembagian kerja (division of labor), karena alasan skala ekonomi, dan karena penyebaran teknologi dan ide. Prinsip kedua didasarkan pada the domestic relative gains, keuntungan perdagangan bagi masyarakat akan didistribusikan secara merata di antara mereka yang terkena dampak perdagangan, kecuali jika ketidaksetaraan manfaat diterima oleh semua anggota masyarakat (misalnya berdasarkan prinsip distribusi domestik). ${ }^{50}$ Dalam hal ini, membandingkan keuntungan dan kerugian perdagangan pada individu hanya diperbolehkan dalam satu negara (single society)..$^{51}$

Prinsip ketiga didasarkan pada the international relative gains principles, manfaat yang diperoleh masyarakat dari perdagangan harus terdistribusikan secara merata, kecuali keuntungan yang tidak sama bagi negara-negara miskin yang diberikan melalui skema khusus perdagangan seperti Generalized System of Preference (GSP). ${ }^{52}$ Dengan asumsi tidak ada yang dirugikan, distribusi keuntungan ke seluruh masyarakat dievaluasi di seluruh negara di dunia. Hal ini terlepas dari kenyataan bahwa prinsip keadilan global secara langsung membatasi keuntungan relatif bagi dua individu dari negara yang berbeda. ${ }^{53}$

Seiring perkembangan hukum perdagangan internasional dewasa ini, terjadi pembedaan pada konsep hukum dalam kaitannya dengan tradisi, norma dan

48 Ibid.

49 Ibid., hlm. 3.

50 Ibid.

51 lbid.

52 Ide pemberian tarif preferensial dalam skema GSP oleh negara maju kepada negara berkembang dan miskin berasal dari Raul Prebisch, Sekretaris Jenderal United Nations Conference on Trade and Development (UNCTAD) pertama pada konferensi UNCTAD pertama tahun 1964. GSP akhirnya diadopsi pada konferensi UNCTAD kedua tahun 1968 di New Delhi, India melalui Resolution 21 (II). Hingga saat ini ada 13 skema GSP nasional yang dinotifikasi ke Sekretariat UNCTAD. Negara pemberi GSP adalah: Australia, Belarus, Bulgaria, Canada, Estonia, the European Union, Japan, New Zealand, Norway, the Russian Federation, Switzerland, Turkey and the United States of America. Selanjutnya, lihat http://unctad.org/en/Pages/DITC/GSP/About-GSP.aspx, diakes tanggal 19 Agustus 2012; Norma Breda dos Santos, Rogerio Farias and Raphael Cunha, "Generalized System of Preferences in General Agreement on Tariffs and Trade/World Trade Organization: History and Current Issues", Journal of World Trade, Vol.39, No.4, 2005, hlm. 637-670.

53 Aaron James, Op.cit, hlm. 4. 
hierarki. Pembedaan konsep ini memengaruhi bentuk jaringan ekonomi yang merupakan bagian integral dari globalisasi ekonomi. ${ }^{54}$ Jaringan ekonomi global adalah produk dari bentuk dan perilaku strategis, yang mana ini semua biasanya memiliki tempat kekuasaan tertentu dan hierarki khusus. ${ }^{55}$ Pada saat yang sama, jaringan ekonomi global menuntut untuk melakukan pelembagaan atas pemerintahan global (constitutionalisation of global governance) dan mewacanakan kelayakan (feasibility) serta keinginan (desirability) atas mereka. ${ }^{56}$ Konsep ini kemudian menghasilkan apa yang disebut sebagai tatanan hukum global (globallaw).

Tatanan hukum global atau yang oleh Snyder disebut sebagai konsep 'global legal pluralism' (pluralisme hukum global) ${ }^{57}$ memunculkan Teori Teubner, yaitu 'Lex Mercatoria as a Paradigm of Global Law'.58 Menurut perspektif Teubner, hukum global memiliki beberapa karakteristik penting. Pertama, batas dari hukum global bukan teritorial, tetapi terdiri dari pasar yang tak terlihat (invisible market), cabangcabang (branches), komunitas profesional yang memiliki keahlian tertentu (specialized professional communities) atau jaringan sosial teknis (technical social network), yang kesemuanya ini melampaui batas-batas teritorial. ${ }^{59} \mathrm{Kedua}$, sumber dari hukum global bukan legislasi (produk hukum), melainkan proses pengorganisasian diri dari struktur hukum dengan proses globalisasi yang sedang berlangsung yang bersifat sangat khusus dan teknis. ${ }^{60}$ Ketiga, hukum global sangat bergantung pada berbagai macam bidang sosial, tidak mandiri dari lembaga politik, oleh karena itu tunduk pada tekanan ekonomi dan karenanya tidak dilembagakan dalam arti "due process" atau "rule of law". ${ }^{61}$ Keempat, hukum global terdiri dari prinsip-prinsip yang luas, yang mana meskipun tidak mengikat secara hukum, memiliki keunggulan dalam hal fleksibilitas dan kemampuan beradaptasi. ${ }^{62}$ Kelima, hukum global pada awalnya tidak dipolitisasi, namun karena perkembangan

\footnotetext{
${ }^{54}$ Francis Snyder, "Governing Economic Globalization: Global Legal Pluralism and EU Law" dalam Francis Snyder (Ed.), Regional and Global Regulation of International Trade, Oxford, Portland: Hart Publishing, 2002, hlm. 8.

55 lbid.

56 Ibid.

57 Ibid.

${ }^{58}$ Gunther Teubner, "Global Bukowina: Legal Pluralism in the World Society" dalam Gunther Teubner (Ed.), Global Law without a State, Dartmouth, Aldershot, 1997, hlm. 3-28. Lex mercatoria oleh Profesor Bernard Audit diartikan sebagai: "...a body of 'spontaneous' law-law created by standard commercial practices and arbitral decisions". Proofesor Schmitthoff menyatakan bahwa lex mercatoria memiliki 4 karakter internasional utama, yaitu: (1) adanya karakteristik seragam mengenai hukum kewajaran; (2) adanya kebiasaan yang berlaku dalam kegiatan atau aktivitas di laut; (3) adanya peradilan yang khusus menangani sengketa komersial; dan (4) adanya kegiatan notaris publik. Selanjutnya, baca Huala Adolf, Arbitrase Komersial Internasional, Edisi Revisi, Jakarta: Rajawali Pers, 2002, hlm. 50-55.

59 Ibid., hlm. 15.

60 Ibid., hlm 8.

61 lbid., hlm. 8, 19.

62 Ibid., hlm. 21.
} 
hubungan ekonomi, lambat laun akan menyebabkan adanya campur tangan dari proses politik. ${ }^{63}$ Keenam, hukum global bersifat tidak terpusat (decentred) dan nonhierarki. ${ }^{64}$

Selanjutnya, global legal pluralism terdiri dari dua aspek. Aspek pertama adalah struktur, dan aspek kedua adalah relasi. ${ }^{65}$ Terkait dengan struktur dapat dijelaskan bahwa pluralisme hukum global meliputi banyak lembaga, norma, dan proses penyelesaian sengketa terletak dan dihasilkan dari lokasi struktur yang berbedabeda di seluruh dunia. Para sarjana hukum biasanya memberikan perhatian lebih pada pemahaman tentang negara, organisasi internasional maupun regional, dan norma hukum yang mengikat serta proses penyelesaian sengketa yang melibatkan hukum. Namun dewasa ini, seiring berkembangnya hukum perdagangan internasional dan integrasi kawasan di berbagai belahan dunia, khususnya Uni Eropa, diskusi mengenai pelembagaan dari hukum perdagangan internasional (institutionalisation of international trade law) ${ }^{66}$ semakin santer dibicarakan oleh para sarjana. Selain itu juga dibicarakan mengenai "multilevel governance", ${ }^{67}$ berbagai macam tipe norma, prosedur, dan proses penyelesaian sengketa yang spesifik, bersifat non-hierarki dan desentralis. ${ }^{68}$

Terkait dengan relasi (hubungan), dapat dijelaskan bahwa global legal pluralism memiliki relasi dengan 'struktur'maupun dengan 'proses'. Relasi global legal pluralism dengan struktur misalnya apakah struktur dari global legal pluralism ini bersifat independen atau merupakan bagian dari rezim yang lain, atau merupakan bagian dari sistem tunggal dari multilevel governance, atau malah keduanya berhubungan. Relasi dengan proses maksudnya apakah proses yang ada dalam global legal pluralism itu berbeda dan saling terpisah, atau saling melengkapi, tumpang tindih atau saling menyediakan satu sama lain. Relasi dari struktur dan proses dari hukum global ini memainkan peran yang penting dalam menentukan karakteristik dari hukum global. ${ }^{69}$

\footnotetext{
63 Ibid.

64 Ibid., hlm. 8.

${ }^{65}$ Francis Snyder, Op.cit., hlm. 10-12.

${ }^{66}$ Ernst-Ulrich Petersmann, "How to Promote the International Rules of Law: Contributions by the WTO Appellate Review System", dalam J. Cameron and K. Campbell (Eds.), Dispute Resolution in the World Trade Organization, London: Cameron May, 1998, hlm. 75; Ernst-Ulrich Petersmann, "Constitutionalism and International Organizations", Nw.J. Intl. L. \& Buss, Vol. 17 Issue 1 (Winter, 1997), hlm. 398-469.

${ }^{67}$ F. Scharpf, Governing in Europe: Effective and Democratic?; Ernst-Ulrich Petersmann, "Multilevel Judicial Governance as Guardian of the Constitutional Unity of International Economic", Loy. L.A. Int'I \& Comp. L. Rev., Vol. 30, 2008, hlm. 367-418.

${ }^{68}$ Risse-Kappen. T., "Exploring the Nature of the Beast: International Relations Theory and Comparative Policy Analysis Meet the European Union", Journal of Common Market Studies, Vol. 34, 1996, hlm. 51.

${ }^{69}$ Francis Snyder, Loc. cit.
} 


\section{Prinsip Keadilan dalam Kerangka WTO}

a. Definisi 'Non-discrimination' dalam Perjanjian WTO

Prinsip keadilan dalam kerangka WTO dinyatakan dengan terminologi 'nondiscrimination'. Prinsip ini merupakan prinsip fundamental ${ }^{70}$ dan menjadi pilar dalam sistem perdagangan dunia. ${ }^{71} \mathrm{Hal}$ ini dapat dicermati pada bagian Pembukaan dari the Marrakesh Agreement Establishing the World Trade Organization (selanjutnya disebut 'The WTO Agreement') yang menyatakan "...the elimination of discriminatory treatment in international trade relation" sebagai salah satu tujuan utama dari WTO.

Prinsip non-diskriminasi dalam perdagangan internasional dapat dilihat dari dua tujuan, yaitu tujuan politik dan ekonomi. ${ }^{72}$ Dari perspektif politik, prinsip nondiskriminasi yang berkaitan dengan urusan luar negeri pada umumnya, dan khususnya berhubungan dengan perdagangan internasional, bertujuan untuk mencegah sengketa diantara negara-negara di dunia. Dalam hal ini, tindakan diskriminasi dapat menimbulkan ketegangan dalam hubungan internasional. Tindakan diskriminatif diartikan sebagai mengenakan perlakuan yang berbeda terhadap dua subjek atau situasi yang sama, baik dengan memberikan keuntungan atau mendukung salah satu subjek atau dengan memberlakukan kerugian atau beban pada subjek lain (imposing unequal treatment of two subjects that are equal or in equal situation, either by granting an advantage or favour to one subject or by imposing a disadvantage or burden on the other subject), tindakan ini dianggap sangat tidak adil. ${ }^{73}$ Perlakuan tidak adil seperti itu dapat menimbulkan dampak yang tidak terbatas terhadap hubungan internasional dan situasi ini memungkinkan menyebabkan perselisihan serius yang pada akhirnya dapat mengarah pada konflik bersenjata. ${ }^{74}$ Sedangkan jika dilihat dari tujuan ekonomi, prinsip non-diskriminasi digunakan sebagai instrumen liberalisasi perdagangan dengan tujuan untuk mencegah inefisiensi. ${ }^{75}$ Berdasarkan teori ekonomi Adam Smith mengenai alokasi sumber daya yang efisien dan keunggulan komparatif, liberalisasi perdagangan

\footnotetext{
70 Julia Ya Qin, “Defining Nondiscrimination Under the Law of the World Trade Organization”, Boston University International Law Journal, Vol. 23, 2005, hlm, 215.

71 Simon Lester, et.al., World Trade Law: Text, Materials and Commentary, Hart Publishing, Oxford, 2008, hlm. 324.

72 Ernst-Ulrich Petersmann, "Economic, Legal and Political Function of the Principle of Non-discrimination", The World Economy, Vol. 9, 1986, hlm. 113-121.

73 Ibid.

${ }^{74}$ Contoh terbaik untuk kasus ini adalah dalam hal pembentukan European Union (EU). Motivasi pembentukan the European Coal and Steel Community (ECSC) tahun 1951 adalah untuk mencapai stabilitas, kemakmuran dan kedamaian Eropa. ECSC membuka jalan bagi penandatanganan the Treaties of Rome (1957) yang menjadi dasar pembentukan European Economic Community (EEC) and the European Atomic Energy Community (Euratom). Tidak mengherankan jika prinsip non-diskriminasi ini memainkan peran yang penting dalam integrasi politik Eropa dengan mengambil posisi penting dalam kerangka perjanjian EU. Selanjutnya, baca Nicolas F. Diebold, Non-discrimination in International Trade in Service: Likeness in WTO/GATS, New York: Cambridge University Press, 2010, hlm. 15-16.

75 Ernst-Ulrich Petersmann, Loc.cit.
} 
memungkinkan suatu negara mengkhususkan diri pada suatu produksi dan ekspor produk dan jasa yang mana mereka memiliki keunggulan komparatif dan pada gilirannya, produk dan jasa impor bisa diproduksi dan dipasok lebih efisien di negara lain. Oleh sebab itu, prinsip non-diskriminasi merupakan salah satu instrumen utama dalam hukum perdagangan internasional yang dirancang untuk mengamankan liberalisasi perdagangan dan menjamin komitmen perdagangan. Prinsip ini berfungsi untuk mencegah adanya perlindungan diskriminatif dari industri dalam negeri atau dari mitra dagang tertentu, sehingga menghindari alokasi sumber daya yang tidak efisien dan distorsi pasar. ${ }^{76}$

Prinsip non-diskriminasi diderivasikan dalam beberapa prinsip di dalam Tthe WTO Agreement, yang mana prinsip ini menjadi kewajiban hukum konkrit (concrete legal obligation) bagi semua anggota WTO. ${ }^{77}$ Diantara prinsip-prinsip tersebut yang paling penting adalah prinsip MFN dan prinsip NT. Namun demikian, kedua prinsip ini memiliki perbedaan dalam penerapan sehubungan dengan perdagangan barang dan jasa. ${ }^{78}$ Kedua prinsip ini terkandung di dalam: General Agreement on Tarriff and Trade (GATT), the General Agreement on Trade in Services (GATS), the Agreement on Trade-Related Aspects of Intellectual Property Rights (TRIPS) dan beberapa perjanjian lain dari WTO. ${ }^{79}$

Prinsip MFN dalam GATT 1994 diatur dalam Pasal 1 (1):

"With respect to customs duties and charges of any kind imposed on or in connexion with importation or exportation or imposed on the international transfer of payments for imports or exports, and with respect to the method of levying such duties and charges, and with respect to all rules and formalities in connexion with importation and exportation...any advantage, favour, privilege or immunity granted by any contracting party to any product originating in or destined for any other country shall be accorded...for the territories of all other contracting Parties."

Pasal ini menyatakan bahwa segala bentuk keuntungan, imbalan, hak istimewa ataupun kekebalan (any advantage, favour, privilege or immunity) yang diberikan oleh satu negara anggota WTO untuk setiap produk yang berasal atau ditujukan

76 Mordeachai E. Kreinin and Michael G. Plummer, "Economic Principles of International Trade”, dalam Patrick F.J. Macrory, Arthur E. Appleton and Michael G. Plummer (Eds), The World Trade Organization: Legal, Economic and Political Analysis, Volume II, New York: Springer, 2005, hlm. 3-22.

77 Simon Lester, Loc.cit.

78 Peter Van den Bossche, The Law and policy, Op.cit., hlm. 309.

79 Sebagai contoh, prinsip MFN ditemukan dalam Pasal 2.2 the Agreement on Safeguard; Pasal 2.1 the Agreement on Technical Barrier to Trade (TBT Agreement); Pasal 2.1 the Agreement on Preshipent Inspection; Pasal 9.2 the Agreement on Implementation of Article VI of the General Agreement on Tarrifs and Trade 1994 (Antidumping Agreement); dan Pasal 19.3 the Agreement on Subsidies and Countervailing Measures (the SCM Agreement). Prinsip NT ditemukan dalam Pasal 2.1 the TBT Agreement, dan Pasal 2 the Agreement on Trade-related Measures (TRIMS). Selain itu, klausa MFN juga terlihat dalam Pasal 3.7 the Understanding on Rules and Procedures Governing the Settlement of Dispute (DSU). Klausa MFN dan NT tampak pada Pasal III the Agreement on Government Procurement (GPA), salah satu dari Perjanjian Plurilateral dari Putaran Uruguay. 
untuk negara lain harus diberikan segera (immediately) dan tanpa syarat (unconditionally) juga kepada produk yang sejenis (like product) yang berasal atau ditujukan ke semua negara anggota WTO yang lain dalam kaitannya dengan: (i) bea masuk dan bea lainnya yang dikenakan dalam hubungannya dengan impor dan ekspor atau dikenakan pada pembayaran transfer internasional untuk impor dan ekspor; (ii) metode pengenaan bea masuk dan bea lainnya; (iii) semua aturan dan formalitas yang berhubungan dengan impor dan ekspor; dan (iv) pengenaan pajak internal dan regulasi yang mempengaruhi penjualan dan penggunaan produk impor. ${ }^{80}$ Dengan kata lain, tujuan dari prinsip MFN ini adalah untuk memastikan kesempatan yang sama (equality of opportunity) untuk mengimpor dari atau mengekspor ke seluruh negara anggota WTO. ${ }^{81} \mathrm{Jadi}$, setiap negara yang memberikan perlakuan istimewa kepada satu negara anggota WTO, ia juga berkewajiban (under obligation) untuk memberikan perlakuan istimewa tersebut kepada seluruh anggota WTO lainnya. ${ }^{82}$ Sedangkan prinsip national treatment pada GATT diatur dalam Pasal III, yang menyatakan:

"The contracting parties recognize that internal taxes and other internal charges, and laws, regulations and requirements affecting the internal sale, offering for sale, purchase, transportation, distribution or use of products, and internal quantitative regulations requiring the mixture, processing or use of products in specified amounts or proportions, should not be applied to imported or domestic products so as to afford protection to domestic production".

Klausa NT mengandung dua hal penting. Pertama, klausa ini melarang negara anggota WTO mengenakan pajak internal atau bea masuk pada produk impor dari negara anggota lain melebihi dari (in excess of) yang diterapkan pada produk domestik yang mirip (like domestic product). ${ }^{83}$ Kedua, mewajibkan negara anggota

80 John H. Jackson, World Trade and the Law of GATT: A Legal Analysis of the General Agreement on Tariffs and Trade, Indianapolis, The Bobbs-Merill Company, 1969, hlm. 256-257.

81 Mistuso Matsushita, et.al., The World Trade Organization: Law, Practice, and Policy, Second Edition, Oxford: Oxford International Law Library, 2006, hlm. 206.

82 Simon Lester, Op.cit., hlm. 322.

83 GATT tidak memberikan penjelasan secara detail mengenai pengertian "produk domestik sejenis" atau "like domestic product". Komisi Banding WTO yang menangangi kasus "the Alcoholic Beverage" memberi pengertian 'like product' sebagai:

there can be no precise and absolute definition of what is 'like'. The concept of 'likeness' is a relative one and evokes the image of an accordion. The accordion of 'likeness' stretches and squeezes in different places as different provisions of the WTO Agreement are applied. The width of the accordion in any one of those places must be determined by the particular provision in which the term 'like' is encountered as well as by the context and the circumstances that prevail in any given case to which that provision may apply.

Mengenai laporan akhir dari Komisi Banding ini selanjutnya lihat: WTO Dispute Appellate Body Report on JapanAlcoholic Beverages, I.T.L.R. vol. 1, iss. 2 at 231 (July 11, 1996). Namun demikian, menurut Regan, untuk mengartikan 'like product' harus memiliki kriteria independen (independent criterion) guna mengetahui tingkat kemiripan yang diperlukan terkait sifat yang relevan. Lebih lanjut mengenai pengertian 'like product', baca: Donald H. Regan, "Regulatory Purpose and 'Like Products' in Article III:4 of the GATT (With Additional Remarks on Article II:2)", J. World Trade, Vol. 36 No. 3, 2002, hlm. 443-478. 
WTO untuk memberikan perlakuan yang tidak merugikan (treatment no less favorable) kepada produk impor dalam rangka memberikan perlindungan pada produk domestik melalui kebijakan internal negara (kebijakan nasional negara anggota). Dengan kata lain, Pasal III GATT ini bertujuan untuk memastikan bahwa produk impor harus diperlakukan sama dengan produk domestik dalam hal pajak (taxation) setelah produk impor tersebut melewati kepabeanan dan juga memberikan perlindungan terhadap produk impor dari tindakan pemerintah yang melindungi produk domestiknya melalui pemberlakuan aturan yang menimbulkan persaingan tidak sehat (unfair competition condition) yang dapat menguntungkan produsen domestik. ${ }^{84}$

\section{b. Prinsip Non-diskriminasi sebagai "Equality of Opportunity"}

Prinsip MFN, NT dan fair competition yang merupakan manifestasi dari prinsip nondiscrimination ini mempunyai makna "equality of opportunity" (kesamaan kesempatan). Prinsip ini memiliki sejarah panjang dalam sistem perdagangan internasional. ${ }^{85}$ Prinsip ini juga telah mengalami evolusi dari waktu ke waktu, disesuaikan dengan perubahan situasi dan diperluas untuk mengakomodasi meluasnya tindakan antar-pemerintah. ${ }^{86}$ Penerapan prinsip ini tidak dapat diragukan telah meningkatkan keadilan dalam sistem perdagangan internasional dengan memastikan negara-negara anggota WTO mendapatkan perlakuan yang sama dari semua mitra dagangnya.

Dimulai pada pertengahan abad ke-19 dan seterusnya, kepatuhan negaranegara anggota WTO terhadap prinsip non-diskriminasi telah mengurangi persaingan dagang yang tidak sehat dan memberikan landasan yang kuat bagi kerja sama perdagangan multilateral. Namun demikian, dalam beberapa tahun terakhir ini, prinsip equality of opportunity ini telah berkurang signifikansi praktisnya dengan munculnya perjanjian regional ${ }^{87}$ dan bilateral. Perkembangan perjanjian regional dan bilateral ${ }^{88}$ ini oleh sebagian pakar dianggap bertentangan dengan ide non-

${ }^{84}$ Edward S. Tsai, “Like is a Four-Letter Word-GATT Article III's 'Like Produk' Conundrum”, Berkeley J.Int'I Law, Vol. 17:26, 1999, hlm. 3.

85 Andrew G. Brown and Robert M. Stern, "Fairness in the WTO Trading System" dalam Amrita, et al (Eds), The Oxford Handbook of The World Trade Organization, Oxford: Oxford University Press, 2012, hlm. 681.

86 lbid.

87 Jagdish N. Bhagwati lebih memilih menggunakan terminologi 'preferential trade agreement/PTA', daripada 'regional trade agreement/RTA'. Hal ini karena PTA tidak selalui meliputi region tertentu dalam arti yang sesungguhnya. Sebagai contoh US-Israel FTA sebenarnya bukan berada dalam satu region. Namun demikian, istilah RTA tetap digunakan di WTO. Jagdish N. Bhagwati, Termites in the Trading System: How Preferential Agreements Undermine Free Trade, New York: Oxford University Press, 2008, hlm. xi.

88 Pada tahun 1990-an, terdapat sekitar 250 RTA telah dinotifikasikan kepada GATT/ WTO. Dari jumlah tersebut, hampir 52 persen dinotifikasi setelah bulan Januari 1995. Dari 250 RTA yang telah dinotifikasi tersebut, lebih dari 170 telah berlaku. Pada akhir tahun 2005, jumlah RTA sudah mendekati 300. Lebih dari separuh perdagangan dunia terjadi dalam kerangka RTA. Kasus yang terjadi di belahan dunia barat misalnya, pada tahun 2004, sekitar 86 persen dari total perdagangan di kawasan tersebut mendapat fasilitas bebas bea masuk sebagai hasil dari pelaksanaan RTA. Hingga tanggal 31 Januari 2014, terdapat 583 notifikasi RTA yang telah diterima oleh 
diskriminasi dan mengurangi berlakunya prinsip equality of opportunity. ${ }^{89}$ Melalui konsep trade diversion, ${ }^{90}$ perjanjian regional dan bilateral dapat dijadikan sarana untuk memperlakukan negara ketiga secara yang sewenang-wenang. ${ }^{91}$

Namun demikian, pembentukan Custom Unions (CU) ${ }^{92}$ dan Free Trade Areas $(\mathrm{FTA})^{93}$ telah diatur di dalam the WTO Agreement. Setiap negara anggota WTO dapat secara bebas menjadi anggota perjanjian prefrerential tanpa melanggar prinsip non-diskriminasi. ${ }^{94}$ Norma ini dianggap tidak konsisten dengan prinsip equality of opportunity, namun secara akademis mendapat pembelaan bahwa norma ini dapat diterapkan karena membawa manfaat yang lebih besar sehingga dapat mengesampingkan prinsip equality of opportunity.$^{95}$

Selanjutnya, prinsip NT juga merupakan ekspresi terbatas dari prinsip equality of opportunity. Prinsip ini terkait erat dengan pengurangan hambatan perdagangan karena negara-negara anggota WTO ingin mendapatkan jaminan bahwa konsesi yang telah didapatkan dalam hal pengurangan hambatan perdagangan tidak akan dikalahkan oleh pengenaan peraturan nasional yang diskriminatif. ${ }^{96}$ Dalam

GATT/WTO. Dari jumlah tersebut, 377 telah berlaku. Lebih lanjut lihat <http://www.wto.org/english /tratop_e/region_e/region_e.htm>.

89 Jagdish Bhagwati, Loc.cit.

90 Trade diversion, yaitu mengalihkan produksi dari negara non-anggota yang efisien ke negara anggota yang efisien. Lebih lanjut mengenai trade diversion dan trade creation, baca R.J.R. Elliot and K. Ikemoto, "AFTA and the Asian Crisis, Help or Hindrance to ASEAN Intra-Regional Trade?", Asian Economic Journal, Vol. 18, No. 1 March 2004, hlm. 16-18.

91 Andrew G. Brown and Robert M. Stern, Op.cit., hlm. 680.

92 Custom union (CU) adalah blok perdagangan regional diantara negara-negara dalam satu kawasan di mana penerimaan bea dan cukai atau custom revenue tiap-tiap anggota yang didapat dari negara di luar anggota dianggap sebagai penerimaan bersama (kolektif), oleh karena itu external tarriff di setiap negara anggota sama bagi suatu produk dari luar kawasan. Sedangkan internal tarriff antar anggota sebesar 0\%. Lebih lanjut, lihat D.H. Hadi, Ekonomi Internasional: Teori dan Kebijakan Perdagangan Internasional, Jakarta: Ghalia Indonesia, 2004, hlm. 89.

93 Kawasan perdagangan bebas atau free trade area (FTA) adalah tipe blok perdagangan di dalam sebuah kawasan, di mana negara-negara anggotanya setuju untuk menghapus tarif dan kuota untuk sebagian besar barang dan jasa yang diperdagangkan di antara mereka. Namun demikian, tiap negara anggota masih mengenakan tarif eksternal untuk barang dan jasa yang berasal dari luar kawasan. Free trade area adalah tingkat dari integrasi ekonomi. Lebih lanjut, lihat Leigh Obradovic, "The Role of Bilateral and Regional Trade Agreement in the Modernisastion of Taxation and Revenue Policy in Developing Economies", World Custom Journal, Vol. 6 No. 2 , 2012, hlm 76-77.

94 Pasal XXIV (4) GATT menyatakan: "The contracting parties recognize the desirability of increasing freedom of trade by the development, through voluntary agreements, of closer integration between the economies of the countries parties to such agreements. They also recognize that the purpose of a customs union or of a free-trade area should be to facilitate trade between the constituent territories and not to raise barriers to the trade of other contracting parties with such territories."

95 Lebih lanjut mengenai kajian integrasi ekonomi, dapat dilihat pada M. Schiff and L.A. Winter, Regional Integration and Development, World Bank, Washington DC, 2003, hlm. 14; Edward D. Mansfield, "The Proliferation of Preferential Trading Agreements", The Journal of Conflict Resolution, Vol. 42 No. 5 (Oktober, 1998), hlm. 523-543; Seymour J. Rubin, "Most-Favored-Nation Treatment and the Multilateral Trade Negotiations: A Quiet Revolution", Md. J. Int'/L, Vol. 6 (2), 1981, hlm. 221-241.

${ }^{96}$ Andrew G. Brown and Robert M. Stern, Op.cit., hlm. 682. 
beberapa dekade terakhir, perhatian negara anggota WTO meningkat pada peran regulasi dalam negeri yang dikhawatirkan dapat menghambat perdagangan internasional serta pada pengawasan praktik nasional yang mungkin dianggap diskriminatif. ${ }^{97}$ Bahkan, sebagian besar pengaduan yang diajukan ke Badan Penyelesaian Sengketa WTO (The WTO Dispute Settlement Body) sejak didirikan pada tahun 1995 banyak yang mempertanyakan mengenai prinsip NT ini. ${ }^{98}$

Prinsip fair competition (persaingan sehat), meskipun kedudukannya dalam The WTO Agreement maupun dalam perjanjian lainnya di dalam WTO tidak seformal prinsip MFN dan NT, juga merupakan perluasan dari prinsip equality of opportunity. Negara anggota WTO ingin memastikan bahwa perusahaan mereka akan mampu bersaing secara sehat dengan perusahaan asing, baik di pasar luar negeri atau dalam negeri, dan aturan perdagangan nasional yang diberlakukan oleh negara anggota WTO tidak boleh berisi norma yang dapat mengganggu lalu lintas perdagangan internasional yang dapat menciptakan keadaan tidak fair. ${ }^{99}$ Sebagai contoh, pelarangan pemberian subsidi yang bertujuan untuk mengurangi biaya produksi, sehingga produk-produk domestik yang dihasilkan oleh suatu negara dapat memiliki keunggulan kompetitif dibanding dengan produk luar. ${ }^{100}$

Setidaknya, sejak berlangsungnya Putaran Uruguay pada tahun 1986, pandangan yang lebih luas mengenai prinsip equality of opportunity telah menjadi topik pembahasan dalam hubungan perdagangan multilateral. ${ }^{101}$ Pada batas ekstrim, prinsip equality of opportunity diartikan bahwa perusahaan-perusahaan dari berbagai negara dapat memiliki akses ke dan untuk melakukan bisnis di setiap pasar di semua negara anggota WTO di bawah regulasi yang sama karena mereka memiliki pasar domestik sendiri. ${ }^{102} \mathrm{Hal}$ ini akan mengakibatkan munculnya pasar tunggal (single market/integrated market). ${ }^{103}$ Namun demikian, masih adanya perbedaan yang sangat mencolok dalam hal kekuasaan, tingkat pembangunan, lembaga, dan sejarah dalam melakukan hubungan dagang, sehingga tampaknya abstraksi yang dibangun ini menjadi jauh dari berguna. ${ }^{104}$ Meskipun kecenderungan pengurangan hambatan perdagangan cukup baik serta terdapat pemusatan terbatas (limited convergence) dalam hal aturan nasional, perbedaan yang signifikan dalam hal substansi hambatan perdagangan dan aturan nasional masing-

\footnotetext{
97 Frieder Roessler, "Diverging Domestic Policies and Multilateral Trade Integration”, dalam Jagdish N. Bhagwati and Robert E. Hudec (Eds), Fair Trade and Harmonization: Prerequisites for Free Trade, Vol. 2: Legal Analysis, Cambridge: The MIT Press, 1997, hlm. 36-44.

98 Andrew G. Brown and Robert M. Stern, "Fairness in the WTO", Op.cit., hlm. 682.

99 Ibid.

100 /bid.

101 lbid.

102 Ibid.

103 Ibid.

${ }^{104}$ Ibid.
} 
masing negara anggota tetap saja ada. ${ }^{105}$ Perbedaan-perbedaan ini bisa bersifat administratif atau teknis seperti perbedaan dalam hal prosedur kepabeanan atau standar teknis. Dalam kasus ini, timbul kesulitan praktis dalam merumuskan aturan umum. ${ }^{106}$

\section{Prinsip Non-diskrinimasi sebagai Keadilan Distributif}

Perbedaan taraf hidup di antara negara-negara di dunia membebankan kewajiban moral (moral obligation) kepada negara maju untuk membantu negara miskin dan berkembang dalam mengentaskan kemiskinan. Pemberian bantuan keuangan (financial aid) adalah ekspresi paling jelas dari kewajiban moral ini, perdagangan internasional juga diterima secara luas sebagai alat untuk melakukan perbaikan ekonomi; dan oleh sebab itu, perdagangan internasional yang saling menguntungkan menjadi sarana untuk mencapai tujuan tersebut. ${ }^{107}$

Selanjutnya, yang menjadi pertanyaan adalah apa yang dimaksud dengan 'perdagangan internasional yang saling menguntungkan' dalam sistem perdagangan internasional? Untuk menjawab pertanyaan ini, maka digunakan konsep keadilan distributif. ${ }^{108}$ Keadilan distributif dalam sistem perdagangan internasional tidak diartikan sebagai cara untuk 'mentransfer' sumber daya dari negara maju ke miskin dan berkembang. ${ }^{109}$ Dalam konteks ini, sistem perdagangan internasional digunakan sebagai sarana untuk mempromosikan hubungan komersial antara perusahaan dan individu di berbagai negara dengan berpegang teguh pada prinsip saling menguntungkan (reciprocity principle). ${ }^{110}$

Hal ini dapat dilakukan melalui dua cara, yaitu: pertama, dengan meningkatkan akses pasar negara miskin dan berkembang;111 kedua, dengan meningkatkan spesialisasi. ${ }^{112}$ Dengan membantu negara miskin dan berkembang mendapatkan akses pasar ke luar negeri, khususnya ke negara-negara maju, hal ini akan berpotensi memberikan kontribusi terhadap pertumbuhan ekonomi negara miskin dan berkembang dengan cara memperbesar pasar untuk produsen dalam negeri mereka. Sedangkan peningkatan spesialisasi bagi negara miskin dan berkembang dalam jangka panjang akan bermanfaat untuk promosi pembelajaran, realisasi

\footnotetext{
105 Ibid.

106 Ibid.

${ }^{107}$ Harold Hongju Koh, "Why Do Nations Obey International Law?", The Yale Law Journal, Vol. 106, 1997, hlm. 25992659.

${ }^{108}$ Philippe Van Parijs, "International Distributive Justice" dalam Robert E. Goodin, Philip Pettit \& Thomas Pogge (Eds), A Companion to Contemporary Political Philosophy, Vol. 2, Oxford: Blackwell, 2007, hlm. 638-652.

109 Ibid.

${ }^{110}$ Kyle Bagwell and Robert W. Staiger, Reciprocity, Non-discrimination and Preferential Agreements in the Multilateral Trading System, Discussion Paper Series No. 9697-14, February 1997, hlm. 1-41.

111 Marco Fugazza and Alessandro Nicita, On the Importance of Market Access for Trade, Policy Issues in International Trade and Commodities Study Series No. 50, UNCTAD, Geneva, 2011, hlm. 3.

${ }^{112}$ Andrew G. Brown and Robert M. Stern, Op.cit., hlm. 683.
} 
eskalasi ekonomi, dan transfer teknologi. ${ }^{113}$ Lebih jauh, spesialisasi bermanfaat juga mendorong perusahaan-perusahaan domestik baru untuk membangun diri, memperluas produksi dan melakukan inovasi sehingga mereka dapat membentuk 'core of an expanding modern sector'. ${ }^{114}$

Akses pasar negara-negara miskin dan berkembang ke negara-negara maju telah lama menjadi feature formal dalam sistem hukum perdagangan internasional. ${ }^{115}$ Negara-negara maju memberikan fasilitas Generalized System of Preferences (GSP) sebagai upaya membantu negara miskin dan berkembang untuk meningkatkan akses pasarnya. ${ }^{116}$ Di satu sisi, pada kenyataannya, sistem ini belum sepenuhnya dimanfaatkan oleh negara miskin dan berkembang. ${ }^{117} \mathrm{Hal}$ ini karena eksportir dari negara miskin dan berkembang mengalami kesulitan dalam memenuhi aturan asal (rules of origin) yang ditetapkan oleh negara pemberi GSP, atau karena biaya transaksi dari proses sertifikasi yang melebihi margin preferensial. ${ }^{118}$ Namun di sisi lain, Cina, menjadi salah contoh luar biasa dalam beberapa tahun terakhir ini, telah mencapai kinerja ekspor yang luar biasa tanpa memanfaatkan skema GSP ini. ${ }^{119}$ Dengan kata lain, dalam sistem perdagangan yang relatif terbuka seperti sekarang ini, faktor penentu yang paling dominan atas kinerja ekspor adalah terletak pada pertumbuhan ekonomi internal, perubahan struktur dan kebijakan yang berorientasi ekspor. ${ }^{120}$

Dalam upaya untuk mempermudah akses pasar atas dasar keadilan distributif, negara-negara miskin dan berkembang meminta kepada negara maju untuk menghapus hambatan perdagangan yang mereka terapkan, khususnya dalam hal tarif dan subsidi di bidang pertanian. ${ }^{121}$ Selama ini, negara-negara maju menerapkan tarif yang tinggi terhadap produk padat karya dan pengolahan produk primer hasil pertanian dari negara-negara miskin dan berkembang. ${ }^{122}$ Poin yang penting dari akses pasar ini adalah bahwa negara-negara miskin dan berkembang harus menikmati fleksibilitas dari pengaturan nasional yang dapat meningkatkan pembangunan negara mereka. ${ }^{123}$

\footnotetext{
113 Ibid.

114 Ibid.

115 Marco Fugazza and Alessandro Nicita, Loc.cit.

116 Norma Breda dos Santos, Rogerio Farias and Raphael Cunha, Loc.cit.

117 Ibid.

118 Ibid.

${ }^{119}$ Andrew G. Brown and Robert M. Stern, Op.cit., hlm. 684.

${ }^{120}$ Ibid.

121 Marco Fugazza and Alessandro Nicita, Loc.cit

$122 \mathrm{Ibid}$.

123 Ibid.
} 


\section{Penutup}

Prinsip keadilan yang terdapat dalam aturan WTO, yang diderivasikan ke dalam prinsip MFN dan NT, mengandung makna 'equality of opportunity' dan 'keadilan distributif'. Equality of opportunity dapat diwujudkan apabila: pertama, ada resiprositas (timbal balik) diantara negara-negara dalam hal pengurangan hambatan perdagangan; kedua, ketika negara-negara patuh terhadap prinsip MFN; ketiga, ketika bias dalam kondisi awal dihapus; keempat, ketika aturan yang mendukung akses pasar tidak hanya dilihat sebagai setara tetapi juga konsisten dengan preferensi nasional suatu negara; dan terakhir keadilan prosedural dihormati dalam hal-hal penyelesaian sengketa dan penggunaan langkah-langkah penyelesaian sengketa perdagangan. Keadilan distributif dalam hukum perdagangan internasional harus dipahami bahwa perdagangan internasional bukan kendaraan untuk melakukan transfer pendapatan tetapi pengaturan (management) perdagangan dengan tujuan untuk menjalin hubungan dagang yang saling menguntungkan diantara negara-negara. Karena perdagangan internasional dianggap dapat membantu mendorong pembangunan negara-negara miskin dan berkembang, maka keadilan distributif di sini berguna untuk menjawab pertanyaan apakah memberikan preferensi terhadap efisiensi pertumbuhan produksi di negara miskin dan berkembang melalui perdagangan di pasar luar negeri maupun dalam negeri.

\section{Daftar Pustaka}

\section{Buku}

A. Posner, Richard, The Problematics of Moral and Legal Theory, The Belknap Press of Harvard University Press, Cambridge, Massachusetts, London, England, 1999.

Bhagwati, Jagdish N., and Robert E. Hudec (Eds), Fair Trade and Harmonization: Prerequisites for Free Trade (Vol. 2: Legal Analysis), The MIT Press, Cambridge, 1997.

Cameron, J., and K. Campbell (Eds.), Dispute Resolution in the World Trade Organization, Cameron May, London, 1998.

D.H. Hadi, Ekonomi Internasional: Teori dan Kebijakan Perdagangan Internasional, Ghalia Indonesia, Jakarta, 2004.

F. Diebold, Nicolas, Non-discrimination in International Trade in Service: Likeness in WTO/GATS, Cambridge University Press, New York, 2010.

Gunther, Teubner, Teubner (Ed.), Global Law without A State, Dartmouth, Aldershot, 1997.

Hornby, A.S., Oxford Advanced Learner's Dictionary of Current English, Sixth Edition, Oxford University Press, Oxford, New York, 2000. 
Huala Adolf, Arbitrase Komersial Internasional, Edisi Revisi, Rajawali Pers, Jakarta, 2002.

H. Jackson, John, World Trade and the Law of GATT: A Legal Analysis of the General Agreement on Tariffs and Trade, The Bobbs-Merill Company, Indianapolis, 1969.

Ibn al-Arabiy, Lisan al-'Arab, Juz 11, Daar Ehia al-Tourath, Beirut, 1999.

Lester, Simon, et.al., World Trade Law: Text, Materials and Commentary, Hart Publishing, Oxford, 2008.

Linarelli, John (Ed.), Research Handbook on Global Justice and International Economic Law, Edward Elgar, Northhampton, 2013.

Matsushita, Mistuso, et.al., The World Trade Organization: Law, Practice, and Policy, Second Edition, Oxford International Law Library, Oxford, 2006.

Narlikar, Amrita, et. al. (Eds), The Oxford Handbook of The World Trade Organization, Oxford University Press, Oxford, 2012.

Nurhasan Ismail, Perkembangan Hukum Pertanahan Pendekatan Ekonomi-Politik (Perubahan Pilihan Kepentingan, Nilai Sosial dan Kelompok Diuntungkan), HuMa, Yogyakarta, 2007.

Pettit, Philip Pettit, and Thomas Pogge (Eds), A Companion to Contemporary Political Philosophy, Vol. 2, Blackwell, Oxford, 2007.

Rawls, John, A Theory of Justice (Revised Edition), Harvard University Press, Cambridge, MA, 1999.

Satjipto Raharjo, Ilmu Hukum, Cetakan Kelima, Alumni, Bandung, 2000.

Scharpf, F., Governing in Europe: Effective and Democratic?, Oxford University Press, New York, 1999.

Schiff, M., and L.A. Winter, Regional Integration and Development, World Bank, Washington DC, 2003.

Snyder, Francis, (Ed.), Regional and Global Regulation of International Trade, Hart Publishing, Oxford, Portland, 2002.

Teguh Prasetyo dan Abdul Halim Barkatullah, Ilmu Hukum dan Filsafat Hukum: Studi

Pemikiran Ahli Hukum Sepanjang Zaman (Cetakan Kedua), Pustaka Pelajar, Yogyakarta, 2006.

Van den Bossche, Peter, The Law and Policy of the World Trade Organization: Text, Cases and Materials, Cambridge University Press, New York, 2005.

\section{Dokumen lain}

Bagwell, Kyle and Robert W. Staiger, Reciprocity, "Non-discrimination and Preferential Agreements in the Multilateral Trading System", Discussion Paper Series No. 9697-14, February 1997.

Breda dos Santos, Norma; Rogerio Farias; and Raphael Cunha, "Generalized System 
of Preferences in General Agreement on Tariffs and Trade/World Trade Organization: History and Current Issues", Journal of World Trade, Vol.39, No.4, 2005.

D. Mansfield, Edward, "The Proliferation of Preferential Trading Agreements", The Journal of Conflict Resolution, Vol. 42 No. 5 (Oktober, 1998).

Fugazza, Marco and Alessandro Nicita, "On the Importance of Market Access for Trade", Policy Issues in International Trade and Commodities Study Series No. 50, UNCTAD, Geneva, 2011.

Hodges, E., Kevin and Daniel P. Sulmasy, "Moral Status, Justice, and the Common Morality: Challeges for the Principlist Account of Moral Change", Kennedy Institute of Ethics Journal, Vol. 23, Number 3, September 2013.

Hongju Koh, Harold, "Why Do Nations Obey International Law?", The Yale Law Journal, Vol. 106, 1997.

H. Regan, Donald, "Regulatory Purpose and 'Like Products' in Article III: 4 of the GATT (With Additional Remarks on Article II: 2)", J. World T rade, Vol. 36 No. 3, 2002.

J. Garcia, Frank, "Three Takes on Global Justice", University of La Verne Law Review, Vol. 31 (2), 2010.

"Globalization, Global Community and the Possibility of Global Justice", Boston College Law School, Paper 33, 2005.

"Why Trade Law Needs a Theory of Justice", Proceedings of the Annual Meeting (American Society of International Law) Vol. 100, 2006.

J. Rubin, Seymour, "Most-Favored-Nation Treatment and the Multilateral Trade Negotiations: A Quiet Revolution", Md. J. Int'IL, Vol. 6 (2), 1981.

J.R. Elliot, R., and K. Ikemoto, "AFTA and the Asian Crisis, Help or Hindrance to ASEAN Intra-Regional Trade?", Asian Economic Journal, Vol. 18, No. 1 March 2004.

James, Aaron, "Theory of Fairness in Trade", Work in progress Faculty Profile System University of California Irvine, Nov. 2008.

L. Dunnoff, Jeffrey, "Rethinking International Trade", PA. J. Int'I Econ. Law, Vol. 19, 1998.

Nagel, Thomas, "The Problem of Global Justice”, Phil. \& Pub. Aff. Vol. 33, 2005.

Obradovic, Leigh, "The Role of Bilateral and Regional Trade Agreement in the Modernisastion of Taxation and Revenue Policy in Developing Economies", World Custom Journal, Vol. 6 No. 2, 2012.

Pauwelyn, Joost, "Just Trade", Geo. Wash.Int'I L. Rev. Vol. 37, 2005. ,"Just Trade Under Law: Do We Need A Theory of Justice for International Trade Relation?", Am. Soc'y Int'I L. Vol. 100, 2006.

Petersmann, Ernst-Ulrich, "Constitutionalism and International Organizations", Nw.J. Intl. L. \& Buss, Vol. 17 Issue 1 (Winter, 1997). 
Petersmann, Ernst-Ulrich "Economic, Legal and Political Function of the Principle of Non-discrimination", The World Economy, Vol. 9, 1986.

Petersmann, Ernst-Ulrich, "Multilevel Judicial Governance as Guardian of the Constitutional Unity of International Economic", Loy. L.A. Int'l \& Comp. L. Rev., Vol. 30, 2008.

S. Tsai, Edward, "Like is a Four-Letter Word-GATT Article III's "Like Produk" Conundrum", BerkeleyJ. Int'I Law, Vol. 17:26, 1999.

Risse-Kappen, T., "Exploring the Nature of the Beast: International Relations Theory and Comparative Policy Analysis Meet the European Union", Journal of Common Market Studies, Vol. 34, 1996.

United Nations Conference on Trade and Development, "About GSP", http://unctad.org/en/Pages/DITC/GSP/About-GSP.aspx, diakes 19 Agustus 2012.

WTO Dispute Appellate Body Report on Japan-Alcoholic Beverages, I.T.L.R. vol. 1, iss. 2 at 231 (July 11, 1996).

Ya Qin, Julia, "Defining Nondiscrimination Under the Law of the World Trade Organization", Boston University International Law Journal, Vol. 23, 2005.

\section{Dokumen Hukum}

The Agreemet on Establishing the World Trade Organization 1994.

The Agreement on Implementation of Article VI of the General Agreement on Tarrifs and Trade 1994.

The Agreement on Government Procurement 1994.

The Agreement on Preshipment Inspection 1994.

The Agreement on Safeguards 1994.

The Agreement on Subsidies and Countervailing Measures 1994.

The Agreement on Technical Barrier to Trade 1994.

The Agreement on Trade-related Investment Measures 1994.

The Understanding on Rules and Procedures Governing the Settlement of Dispute 1994. 